\title{
Adverse effects of wastewater discharges in reproduction, energy budget, neuroendocrine and inflammation processes observed in marine clams Ruditapes philippinarum
}

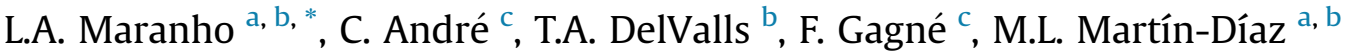 \\ a Andalusian Centre of Marine Science and Technology (CACYTMAR), University of Cádiz, Polygon Río San Pedro, s/n, 11510, Puerto Real, Cádiz, Spain \\ ${ }^{\mathrm{b}}$ UNITWIN/UNESCO/WiCoP, Physical Chemical Department, Faculty of Marine and Environmental Sciences, University of Cádiz, Polygon Río San Pedro, s/n, \\ 11510, Puerto Real, Cádiz, Spain \\ ${ }^{\mathrm{c}}$ Emerging Methods, Aquatic Ecosystem Research, Environment Canada, 105 McGill Street, 7thfloor, H2Y 2E7, Montreal, Quebec, Canada
}

\section{A R T I C L E I N F O}

\section{Article history:}

Received 21 January 2015

Received in revised form

8 June 2015

Accepted 30 July 2015

Available online 6 August 2015

\section{Keywords:}

Seasonality

Ruditapes philippinarum

Wastewater discharges

Energy status

Neuroendocrine assessment

Impaired reproduction

\begin{abstract}
A B S T R A C T
The present study investigated possible adverse outcomes in the marine clams Ruditapes philippinarum exposed to sediment affected by wastewater discharges at the Bay of Cádiz (SW, Spain). Six locations representing five cities were chosen for the sediment sampling during winter and summer seasons: P1 Chiclana de la Frontera, P2 - Puerto Real, P3 - Cádiz, P4 and P5 - El Puerto de Santa María, P6 - Rota (reference site). Biochemical biomarkers were explored in clams after 14-days of exposure under controlled conditions, that included changes in cellular energy status (total lipids content - TLP and mitochondrial electron transport activity - MET), gametogenic activity (dopamine and ALP levels), metabolism of monoamines (monoamine oxidase activity - MAO), inflammation and spawning properties (cyclooxygenase activity - COX). Wastewater discharges induced energy budget alterations, as suggested by MET decrease (P4 and P5) and accumulation of TLP (P1, P2 and P3) in gonads. ALP levels (P1, P2 and P3), dopamine (P2) and COX activity (P1, P2, P3, P4 and P5) decreased in clams after the exposure to summer sediments. MAO increased in clams exposed to winter (P1 and P2) and summer (P3 and P4) sediments. Wastewater discharges composition changed between different seasons, mainly leading to oxidative stress, inflammation (COX activity and ALP levels) and spawning delay in summer. This study highlights the importance of considering reproduction of marine biota when assessing adverse effects of wastewater discharges. Continuous release of wastewater adequately threated or not, in aquatic ecosystems may culminate in adverse effects to the local benthic biota.
\end{abstract}

(c) 2015 Elsevier Ltd. All rights reserved.

\section{Introduction}

Wastewater discharges and sewage outfalls drive large amounts of effluents to estuaries and marine environments, which contain a plethora of contaminants including metals, polycyclic aromatic hydrocarbons (PAH), pesticides, steroids, surfactants, nutrients and pharmaceutical and personal care products (PPCP). Marine and estuarine environments are the major receptor of wastewater discharges from coastal areas, where the most urban populated areas in the world are located (Lara-Martín et al., 2014). Although a

\footnotetext{
* Corresponding author. Current address: São Paulo State University - UNESP, Câmpus Experimental do Litoral Paulista, Praça Infante Dom Henrique, s/n - Parque Bitarú, São Vicente - SP, 11330-900, Brazil.
}

E-mail addresses: Imaranho@gmail.com, luciane.alves@uca.es (L.A. Maranho). variety of РPCP have been currently detected in the marine environment (Lara-Martín et al., 2014; Long et al., 2013), only few studies have addressed the wastewater exposure and effects on non-target species (Vidal-Dorsch et al., 2014; Beyer et al., 2013; Maruya et al., 2012).

The Water Framework Directive (WFD) recommends the use of biota for assessing contamination trends in water bodies (Gust et al., 2014). Sensitivity of the molluscs to mixture of contaminants has been explored to evaluate chronic adverse effects of municipal effluents as biochemical and immunochemical responses (Box et al., 2007; Solé et al., 2009; Franzellitti et al., 2010; Gagné et al., 2011). Functional changes at cellular levels as neuroendocrine effects (monoamine oxidase activity - MAO, dopamine levels), inflammation (cyclooxygenase activity - COX), changes in reproduction (ALP levels) and energy status (total lipids content - 
TLP, mitochondrial electron transport - MET) were previously assessed in freshwater molluscs. Wastewater treatment plant (WWTP) effluents produced inflammation measured by cyclooxygenase activity (COX) in mussels Elliptio complanata (Gagné et al., 2008a, 2007a, 2005) and snails Lymnaea stagnalis (Gust et al., 2013). Neuroendocrine toxicity and oestrogenic activity of primary-treated municipal effluents were assessed on E. complanata through the determination of monoamine oxidase (MAO) activity (Gagné et al., 2007a,b) and Vtg-like proteins applying ALP assay (Gagné et al., 2007b). Evidence of feminization was confirmed in E. complanata exposed to municipal effluents through the measurements of COX activity, serotonin, dopamine and Vtg-like proteins (Gagné et al., 2011). Freshwater organisms exposed to effluents increased energy expenditure determined by mitochondrial electron transport activity (MET) and total lipids (TLP) reduction (Gagné et al., 2007a; Smolders et al., 2004).

Marine bivalves, such as clams Ruditapes philippinarum are considered as sensitive bioindicators exposed to chronic water/ sediment pollution. This species has been extensively used in biomonitoring (Morales-Caselles et al., 2008; Moschino et al., 2011) and sublethal studies (Buratti et al., 2010, 2012; Coughlan et al., 2009; Martín-Díaz et al., 2008b, 2007, 2005). Research on neuroendocrine responses in marine bivalves to stressors and their application in biomonitoring studies is not as extensive on biochemical biomarkers (Gagné at al., 2008b, Matozzo and Marin, 2007). Reproduction aspects have particular relevance to monitor population dynamics in contaminated environments (Solé et al., 2003; Martín-Díaz et al., 2008a; Matozzo et al., 2008).

The aim of the present study was to evaluate sublethal stress responses of bivalve sentinel organisms exposed to sediment contaminated by wastewater discharges, and to discuss the suitability of this bioindicator. Five different locations (P1 - P5) representing four cities (SW, Spain) were selected under directly influence of wastewater discharges and compared with a reference site (P6). 14-days bioassay with marine clams ( $R$. philippinarum) was performed under laboratory conditions. Changes in total lipids (energy reserves), mitochondrial electron transport (energy consumption), cyclooxygenase activity (inflammation properties), monoamine oxidase activity and dopamine levels (neuroendocrine effects), and ALP levels (reproduction) were determined in gonads taking into account seasonality and contamination.

\section{Material and methods}

\subsection{General approach}

The Bay of Cádiz (SW, Spain) comprises a population of 460,000 habitants, but during the summer season the population increases by $30 \%$ compared with winter owing to tourism (INE, 2011). There is an increase of some PPCPs use (e.g. sunscreen in summer) in each season, and the decrease of others (e.g. cold medications in summer). Summer in South Spain is a dry season, and consequently, water consumption increases. However, winter comes with strong storms, which deal with sediment resuspension in the studied areas, and as a consequence, contaminants accumulated in the sediment compartment tend to be bioavailable to the aquatic biota. Main industries located in this zone are related with ship, offshore, car and aerospace manufacturing. Agriculture and tourism are also important socio-economic activities at the Bay of Cádiz.

Six points were chosen at the Bay of Cádiz (SW, Spain) (Fig. 1) for the assessment of sediment toxicity. Five of them were under the influence of wastewater discharges from urban areas: P1 - Chiclana de la Frontera, P2 - Puerto Real, P3 - Cádiz, P4 and P5 - El Puerto de Santa Maria. Previous studies recognized these areas as directly affected by wastewater discharges (Lara-Martín et al.,

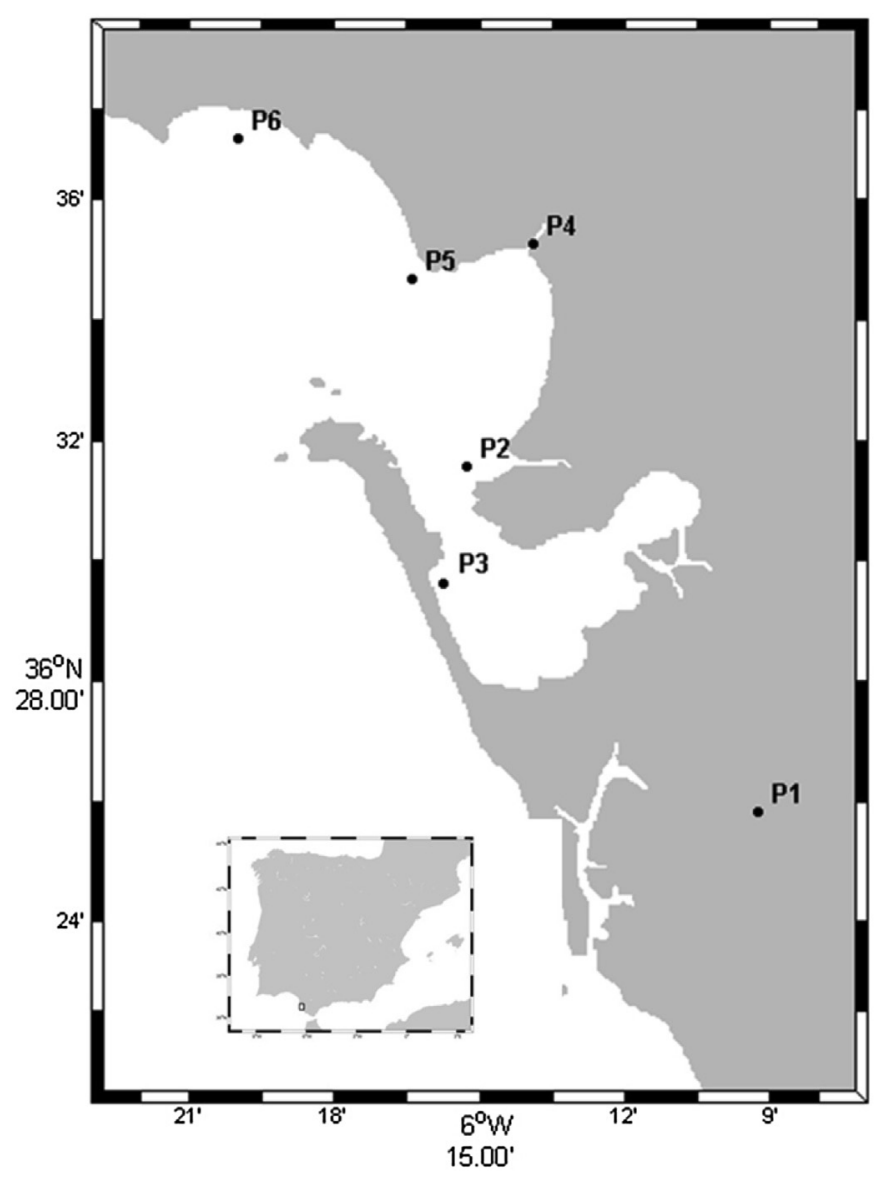

Fig. 1. Geographic locations of sampling regions across the Bay of Cádiz (SW, Spain). Five sampling sites representing urban areas were selected to the sediment collection near wastewater discharges: Chiclana de la Frontera (P1), Puerto Real (P2), Cádiz (P3), El Puerto de Santa Maria (P4 and P5), and ending with the reference site in Rota (P6).

2008; Carrasco et al., 2003; Ponce et al., 2000), also regarded to maps provided by Junta de Andalucía (Spanish Government). P6 was located at Rota, and chosen as reference site.

- Chiclana de la Frontera (P1): located at Iro River. Previous study speculated the discharge of anticholinergic agents, such as pesticides (Solé et al., 2009). This river receives water from agricultural sources as well as urban wastewater discharge. Although the wastewater is treated in a WWTP before the discharge, a high level of contamination by nutrients and pathogens were measured in the aquatic system (Garrido-Pérez et al., 2002);

- Puerto Real (P2): characterized by WWTP discharge, moderate metal contamination (Carrasco et al., 2003) and significant shipping activity;

- Cádiz (P3): this area support a seasonal wastewater pumping and storage station, that send the wastewater to be treated in another WWTP located at San Fernando. However, there are occasional discharges of wastewater from this station to the Bay of Cádiz;

- El Puerto de Santa Maria (P4 and P5): P4 is characterized by seasonal wastewater pumping, and also receives the effluents coming from the upper part of the Guadalete River. SAS were previously detected in sediment in this area which correlated their usage and the presence of wastewater discharges (LaraMartín et al., 2006). Some marinas and small harbours are located in this point. P4 might be considered the main receiving 
point for wastewater generated in the upstream regions of the Cádiz province. P5 is located near a sewage outfall in the north of the Bay of Cádiz, at Puerto Sherry, which receives WWTP effluents from the city. There are only occasionally untreated discharges since WWTP has existed for several years (LaraMartín et al., 2006).

- Rota (P6): far from known wastewater discharges, with a high water renewal, near the Chorillo sandy beach.

\subsection{Sediment sampling}

Sediment was sampled during winter and summer 2011, from an inflatable launch on an ebbing tide by means of Van Veen grab (when it was possible) or scuba divers help, taking the topmost $10 \mathrm{~cm}$ layer of the sediments. Samples were brought to the laboratory, sieved to remove large debris and other animals, and kept at $4{ }^{\circ} \mathrm{C}$ in the dark for maximum two days until the clams' exposure. Sediment samples were placed in 20-L aquarium filled with filtered seawater.

Physical chemical characteristics of the sediment sampled at P1 - P6 in winter and summer seasons were described in Tables 1 and 2. For sediment grain size analysis, an aliquot of dry sediment was analysed following the methodology recommended by USGS (2000). Total organic carbon (TOC) and organic matter (OM) content were evaluated (USEPA, 2002). Aqua regia extraction (ISO11466, 1995) was applied for metal analyses. Concentrations of metals ( $\mathrm{Al}, \mathrm{As}, \mathrm{Cd}, \mathrm{Cr}, \mathrm{Cu}, \mathrm{Fe}, \mathrm{Mn}, \mathrm{Ni}, \mathrm{Pb}$, Se and $\mathrm{Zn}$ ) were quantified by inductively coupled plasma optical emission spectrometry (ICPOES). Hg concentrations were determined with LECO AMA 254 analyser. Results were checked using MESS-1 NRC reference material. Such metals were chosen based on sediment quality guidelines (SQG): USEPA (2004), CCME (1995), CEDEX (1994) and Riba et al. (2004).

Concerning organic compounds, polycyclic aromatic hydrocarbons (PAHs) in sediment samples were analysed according to USEPA SW-846 method 8270/8082 (2007). PAH fractions were chosen based on Riba et al. (2004). The sum of PAH fractions was used for the integrative analysis.

Selected 34 pharmaceuticals and secondary alkane sulfonates (SAS) were measured following methods proposed by Jelic et al. (2009) and Baena-Nogueras et al. (2013). Pharmaceuticals determined were anti-inflammatories (acetaminophen, diclofenac, fenoprofen), anti-hypertensive (atenolol, propranolol), lipid regulators (clofibric acid, gemfibrozil), psychiatric drugs (carbamazepine, fluoxetine, amitriptyline, caffeine), antibiotics (chloramphenicol, cefdinir, tiamulin, erythromycin, clarithromycin, azithromycin, roxithromycin, lincomycin, clindamycin, flumequine, sparfloxacin, novobiocin, metronidazole, ornidazole, sulfadiazine, sulfamethoxypyridazine, sulfathiazole, trimethoprim, monensin), antacids (famotidine, ranitidine) and others (glibenclamide, hydrochlorothiazide). The sum of each group of pharmaceuticals was used for the integrative analysis. For additional information about chemicals analysis, please see Maranho et al. (2015, 2014).

\subsection{Clams exposure and tissues preparation}

Specimens of $R$. philippinarum were bought from an aquaculture farm located at Chiclana de la Frontera (SW, Spain). Samples consisted of clams with $35-45-\mathrm{mm}$ shell length. These specimens were acclimatised in the laboratory for 7 days before exposure. After the acclimation period, 28 individuals were placed to each aquarium (day-0). The bioassay was performed in duplicate. Conditions of the bioassay were verified each two days $(\mathrm{pH}: 8.1 \pm .3$, dissolved oxygen: $7.3 \mathrm{mg} \mathrm{L}^{-1} \pm .2$, salinity: $35.3 \pm 1.4$ ). $1: 3$ of the
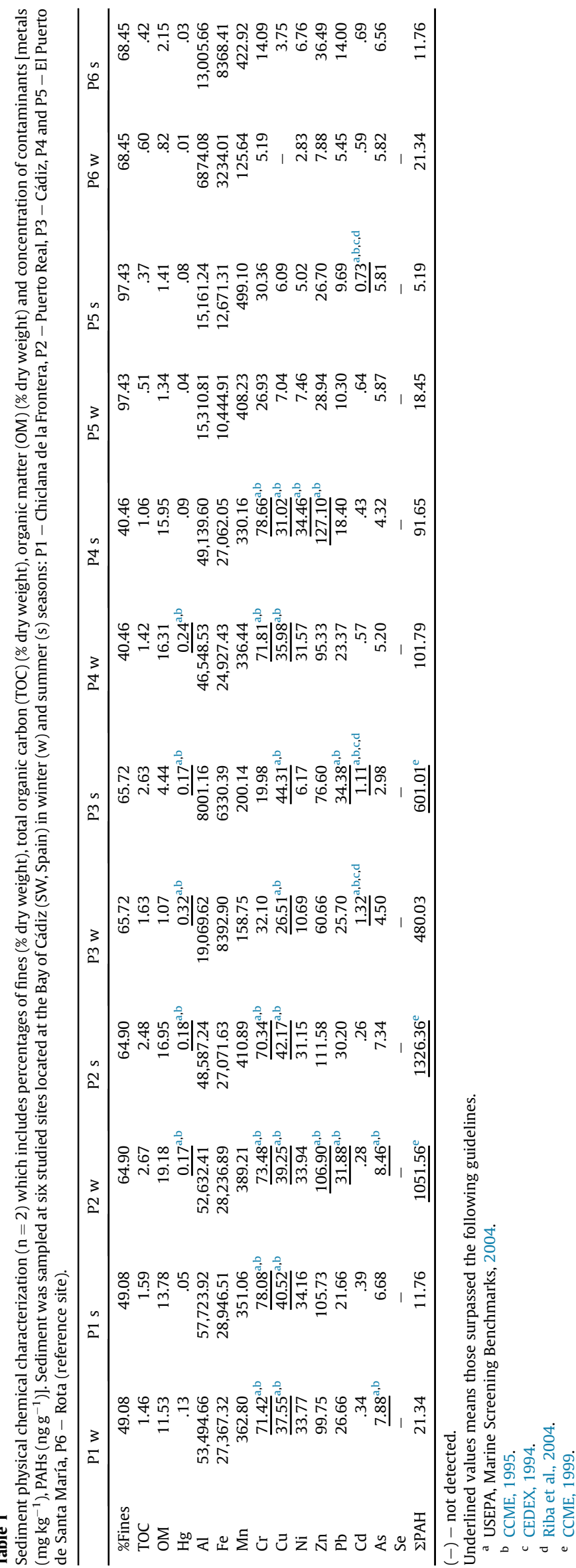
Table 2

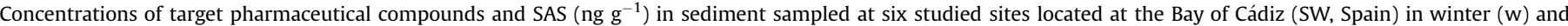
summer (s) seasons: P1 - Chiclana de la Frontera, P2 - Puerto Real, P3 - Cádiz, P4 and P5 - El Puerto de Santa María, P6 - Rota (reference site).

\begin{tabular}{|c|c|c|c|c|c|c|c|c|c|c|c|c|}
\hline & P1 w & P1 s & P2 w & P2 s & P3 w & P3 s & $\mathrm{P} 4 \mathrm{w}$ & P4 s & P5 w & P5 s & P6 w & P6 s \\
\hline Anti-inflammatories & 27.1 & 30.3 & 9.4 & .1 & 2.9 & .9 & 16.4 & .8 & 1.9 & 2.2 & 5.9 & 8.3 \\
\hline Anti-hypertensive & .5 & .5 & .1 & .3 & .2 & .6 & 1.1 & .6 & .2 & .1 & .1 & .3 \\
\hline Lipid regulators & 1 & .4 & .1 & .1 & - & - & .1 & .1 & - & - & - & - \\
\hline Psychiatric drugs & 4 & 13.2 & 2 & 3.2 & 3.5 & 4.7 & 9 & 8.9 & 97.5 & 5 & 8.9 & 3.3 \\
\hline Antibiotics & 3.5 & 3.6 & 20.6 & 2.1 & 13.4 & 1.9 & 4.6 & 2.5 & 28.8 & 2.4 & 8.8 & 2 \\
\hline Antacids & .4 & .7 & .7 & .3 & .1 & .3 & 1.1 & .2 & .3 & .3 & .2 & .1 \\
\hline Others & 1.1 & 2.1 & 1.2 & 1.5 & .3 & 1 & 1.1 & .8 & .2 & - & - & .1 \\
\hline SAS & 1978.65 & 1521.0 & 61.1 & 77.4 & 73.9 & 44.7 & 1147.9 & 2344.8 & 400.7 & 159.3 & 623.2 & 118.7 \\
\hline
\end{tabular}

$(-)-$ not detected.

seawater was renewed each three days. Exposure period lasted 14 days at $18 \pm 2{ }^{\circ} \mathrm{C}$, photoperiod $12 \mathrm{~h}$ light: $12 \mathrm{~h}$ dark, under constant aeration.

At the end of the exposure period, clams were placed overnight in aquariums filled with filtered seawater $\left(18 \pm 2{ }^{\circ} \mathrm{C}\right)$ for depuration. Twelve clams from each duplicate $(\mathrm{n}=24$ clams) were chosen randomly for the biomarker analysis. Gonad mass were dissected out, pooled ( $\mathrm{n}=4$ gonads) and homogenized on ice using Teflon pestle tissue grinder apparatus in homogenization buffer (pH 7.5) containing $140 \mathrm{mM} \mathrm{NaCl}, 25 \mathrm{mM}$ Hepes-NaOH, $.1 \mathrm{mM}$ EDTA and $.1 \mathrm{mM}$ dithiothreitol (DTT) (Gagné et al., 2007a). A portion of homogenate was centrifuged at $3,000 \mathrm{~g}$ at $4{ }^{\circ} \mathrm{C}$ for $20 \mathrm{~min}$, and the supernatant fraction carefully collected $\left(\mathrm{S}_{3}\right.$ fraction). Other aliquot of homogenized fraction was centrifuged at $15,000 \mathrm{~g}$ at $4{ }^{\circ} \mathrm{C}$ for $20 \mathrm{~min}$, and the supernatant used for biomarker determinations ( $\mathrm{S}_{15}$ fraction). Homogenate, $\mathrm{S}_{3}$ and $\mathrm{S}_{15}$ fractions were stored at $-80{ }^{\circ} \mathrm{C}$ until further analysis.

Total protein content (mg) was determined to each extract according to Bradford method (1976) using serum bovine for calibration.

\subsection{Neuroendocrine parameters - dopamine levels and monoamine oxidase activity}

Dopamine levels were determined in the $S_{15}$ fraction using a competitive enzyme-linked immunosorbent assay (ELISA) (Kim et al., 2008) with modifications (Gagné et al., 2011). First, 96-well luminescence plates (Microlite 2, Thermo Fisher Scientific, ON, Canada) were coated with $.5 \mu \mathrm{g}$ of BSA-conjugated dopamine (US Biological, Boston, MA, USA) in $50 \mathrm{mM}$ Tris- $\mathrm{HCl}\left(\mathrm{pH} \mathrm{8.5)}\right.$ at $4{ }^{\circ} \mathrm{C}$ overnight. Plates were washed three times with PBS (5 mM $\left.\mathrm{KH}_{2} \mathrm{PO}_{4}, 1 \mathrm{mM} \mathrm{NaHCO}, 150 \mathrm{mM} \mathrm{NaCl}, \mathrm{pH} 7.4\right)$ and incubated in blocking buffer (1\% dry milk in PBS) for $90 \mathrm{~min}$ at room temperature with constant shaking. Dopamine standard were diluted in buffer (.5\% dry milk in PBS) in ranging concentration from 1 to $1000 \mu \mathrm{M}$ and $.5-1000 \mu \mathrm{M}$, respectively. Plates were washed with PBS and standards, and pre-diluted samples were added to the wells followed by an addition of primary antibody 1:5000 (Rabbit polyclonal to dopamine ab888, Abcam, MA, USA). Plates were washed three times with PBS, and incubated with HRP conjugated goat anti-rabbit IgG (1:10,000, Stressgen, MI, USA) for an hour after which unbound HRP-conjugate antibodies were removed. Wells were washed three times with PBS, and HRP substrate solution (BM Chemiluminescence ELISA Substrate, Roche Diagnostics, QC, Canada) was added in the microplate. Chemiluminescence intensity was measured using Chameleon plate reader (Hidex, Finland). Data were expressed as $\mu \mathrm{mol}$ dopamine/mg protein.

MAO activity was determined using serotonin analogue tryptamine as the substrate (Gagné et al., 2007b). Homogenate extracts were incubated in a solution of $10 \mu \mathrm{M}$ dichlorofluorescein, $1 \mathrm{mM}$ tryptamine in $10 \mathrm{mM}$ Hepes- $\mathrm{NaOH}(\mathrm{pH} 7.4)$, containing $140 \mathrm{mM}$
$\mathrm{NaCl}, 10 \mathrm{mM}$ aminotriazole and $.1 \mu \mathrm{g} \mathrm{ml}^{-1}$ of horseradish peroxidase for $0,15,30$ and $60 \mathrm{~min}$ at $30^{\circ} \mathrm{C}$. Fluorescence was measured at $485 \mathrm{~nm}$ and $535 \mathrm{~nm}$. Activity was expressed as nmol RFU/min/mg proteins.

\subsection{Oestrogenic activity assessment}

Alkali-labile phosphate (ALP) method was applied in homogenized extracts as described by Gagné et al. (2003). Proteins were precipitated by acetone $(35 \% \mathrm{v} / \mathrm{v})$, centrifuged at $10,000 \mathrm{~g}$ for 5 min at $4{ }^{\circ} \mathrm{C}$ and washed in $50 \%$ acetone. After this, the sample was re-centrifuged, resuspended in $100 \mu \mathrm{L}$ of $1 \mathrm{M} \mathrm{NaOH}$ and incubated for $30 \mathrm{~min}$ at $60{ }^{\circ} \mathrm{C}$. Levels of inorganic phosphates liberated from $\mathrm{NaOH}$ treatment were determined by phosphomolybdate assay (Stanton, 1968). Absorbance was measured at $444 \mathrm{~nm}$ (some cases with interferences in the colour, the reading was taken at $815 \mathrm{~nm}$ ). Data were expressed as $\mu \mathrm{g}$ ALP/mg proteins.

\subsection{Inflammation biomarker}

Cyclooxygenase (COX) activity was tracked by measuring the oxidation of 2, 7 - dichlorofluorescein in the presence of arachidonate in $\mathrm{S}_{15}$ fractions (Fujimoto et al., 2002). The S15 fraction was incubated in $50 \mathrm{mM}$ Tris- $\mathrm{HCl}, .05 \%$ Tween-20, $50 \mu \mathrm{M}$ arachidonate, $2 \mu \mathrm{M}$ dichlorofluorescein and $.1 \mu \mathrm{g} \mathrm{ml}^{-1}$ horseradish peroxidase. Fluorescence was measured at $485 \mathrm{~nm}$ and $530 \mathrm{~nm}$. COX activity was expressed as $\mathrm{RFU} / \mathrm{min} / \mathrm{mg}$ proteins.

\subsection{Energy budget}

Total lipids (TLP) were determined in homogenate samples according to the phosphovanillin method (Frings et al., 1972). Samples were incubated for $10 \mathrm{~min}$ at $80{ }^{\circ} \mathrm{C}$ in the presence of $\mathrm{H}_{2} \mathrm{SO}_{4}$ and phosphovanillin reagent. The appearance of pink color was measured at $540 \mathrm{~nm}$. Standard solutions of olive oil were used for calibration. Data were expressed as $\mu \mathrm{g} \mathrm{TLP} / \mathrm{mg}$ proteins.

Mitochondrial electron transport (MET) activity was determined according to reduction of p-iodonitrotetrazolium dye method (Smolders et al., 2004; King and Packard, 1975). The $S_{3}$ fractions were mixed with buffer composed by $.1 \mathrm{M}$ Tris- $\mathrm{HCl}$ containing $.1 \mathrm{mM} \mathrm{MgSO}_{4}, .1 \%$ Triton X-100 and $5 \%$ polyvinylpyrrolidone $(\mathrm{pH}$ 8.5 ) for $1 \mathrm{~min}$, followed by the addition of $1 \mathrm{mM} \mathrm{NADH}, .2 \mathrm{mM}$ $\mathrm{NAPDH}$ and $1 \mathrm{mM}$ p-iodonitrotetrazolium. Absorbance readings were taken at $520 \mathrm{~nm}$ each $5 \mathrm{~min}$ for $30 \mathrm{~min}$. Data were expressed as A $520 \mathrm{~nm} / \mathrm{min} / \mathrm{mg}$ proteins.

\subsection{Data analysis}

Normality and homogeneity of biomarker data were tested using Shapiro Wilk's and Bartlett's tests, respectively. Data were subjected to one-way Analysis of Variance (ANOVA) followed by 
Dunnett's t test. Significance was set at $\mathrm{p}<0.05$. Spearman's rank correlation was performed to detect significant trends between biomarker responses determined in clams exposed to each sediment sample point and between seasons. Significance was set at $\mathrm{p}<0.05$. Two separate PCAs were conducted on the biological and chemical results, one for winter, and the other one for summer. Only the variables whose coefficient was $\geq .5$ (Comrey's, 1973) were considered to be components of the factors. All responses were analysed using the SPSS/PC $21.0+$ statistical package.

\section{Results}

\subsection{Physical chemical data}

Grain size distribution indicated three overall groups predominated: essentially clayed silt sediments (P1, P2 and P4), medium sand (P3) and predominance of sand (P5 and P6) with fairly significant gravel and sand content. P2 showed the highest levels of TOC and OM during winter and summer. To evaluate potential ecotoxicological effects associated with observed concentrations of metals and PAHs, different published Sediment Quality Guidelines (SQGs) were consulted. Contaminants that exceeded any SQGs were highlighted in Table 1 . The letter superscripted indicated which SQGs were surpassed for metals (USEPA, Marine Screening Benchmarks, 2004, CCME, 1995; CEDEX, 1994, Riba et al., 2004) and PAHs (CCME, 1999). Chemical results indicated P1, P2, P3, P4 and P5 were contaminated by organic and inorganic contaminants (metals and PAHs). P1 both seasons and P4 summer showed the highest concentration of SAS (Table 2). Anti-inflammatory concentrations were higher in sediment sampled at P1 than the other sites for both seasons. P5 winter also showed the highest concentration of psychiatric drugs and antibiotics.

\subsection{Biomarker responses}

Neuroendocrine parameters, energy budget and inflammation state of clams exposed to marine sediments contaminated by effluent discharges from WWTPs located at the Bay of Cádiz (SW, Spain) were investigated. Although there was no mortality of clams exposed to sediment sampled in the summer season, increasing of clam's mortality was observed during the winter season: P1 $32.1 \%$, P2 - 21.4\%, P3 - 26.7\%, P4 - 50\%, P5 - 7.14\%, P6 - 15\% in the reference site.

Biomarker responses were examined in pooled samples of clams exposed to sediment samples affected by wastewater discharges (Figs. 2-7). There was no significant difference of dopamine levels in winter season (Fig. 2). Clams exposed to sediments from P2 showed significantly lower dopamine levels (2-fold) compared with the reference site during the summer season $(p<0.05)$.

During the winter season, clams exposed to sediments affected by wastewater discharges P1 and P2 showed significant MAO activity reaching 2-fold higher compared with the reference site ( $p<0.05$ ) (Fig. 3). However, clams exposed to sediments from P3 and P4 significantly increased MAO activity $(\mathrm{p}<0.05)$ in summer, which was found 1.9 and 2.6-fold higher than the reference site, respectively.

ALP levels were higher in summer than winter (Fig. 4). P1 (2.2fold), P3 (1.6-fold) and P4 (2.2-fold) were significantly lower compared with the reference site $(\mathrm{p}<0.05)$ during winter.

COX activity (Fig. 5) increased in summer compared with winter including clams exposed to sediment sampled at the reference site. Nevertheless, COX activity was significantly decreased compared with the reference site $(\mathrm{p}<0.05)$ during the summer season for all stations (P1: 2.3-fold, P2: 3.5-fold, P3: 1.9-fold, P4: 2.9-fold, P5: 1.9fold).

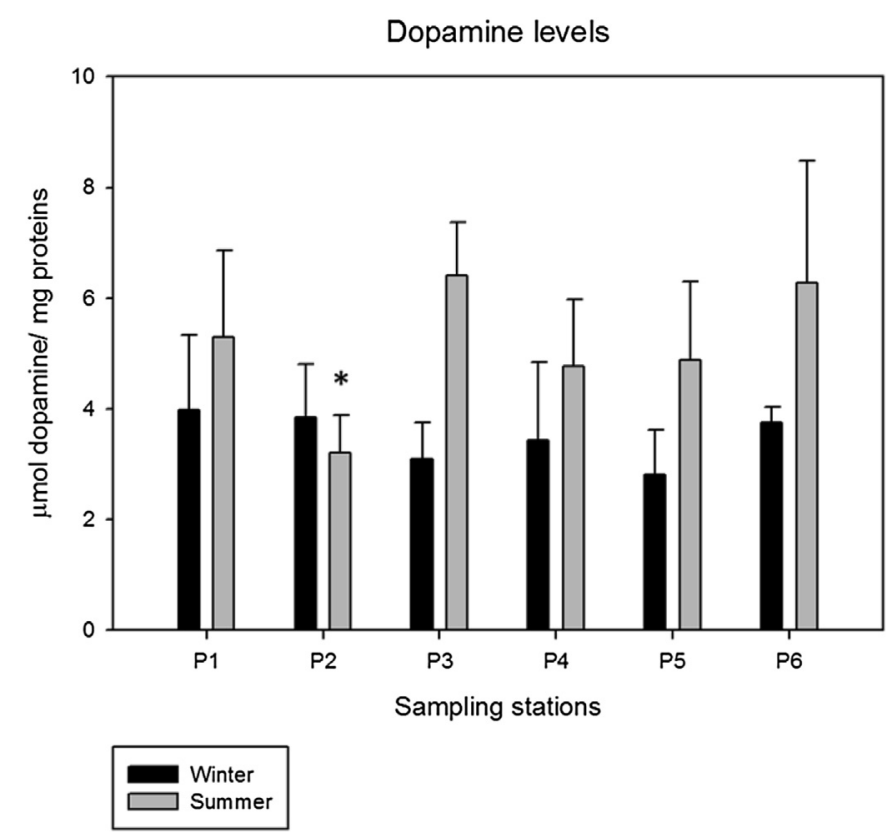

Fig. 2. Dopamine levels in clams exposed to marine sediment affected by wastewater discharges. Clams $R$. philippinarum were exposed to sediments for 14-days under laboratory conditions. Asterisks $\left({ }^{*}\right)$ indicate significance at $\mathrm{p}<0.05$ level in respect to control clams.

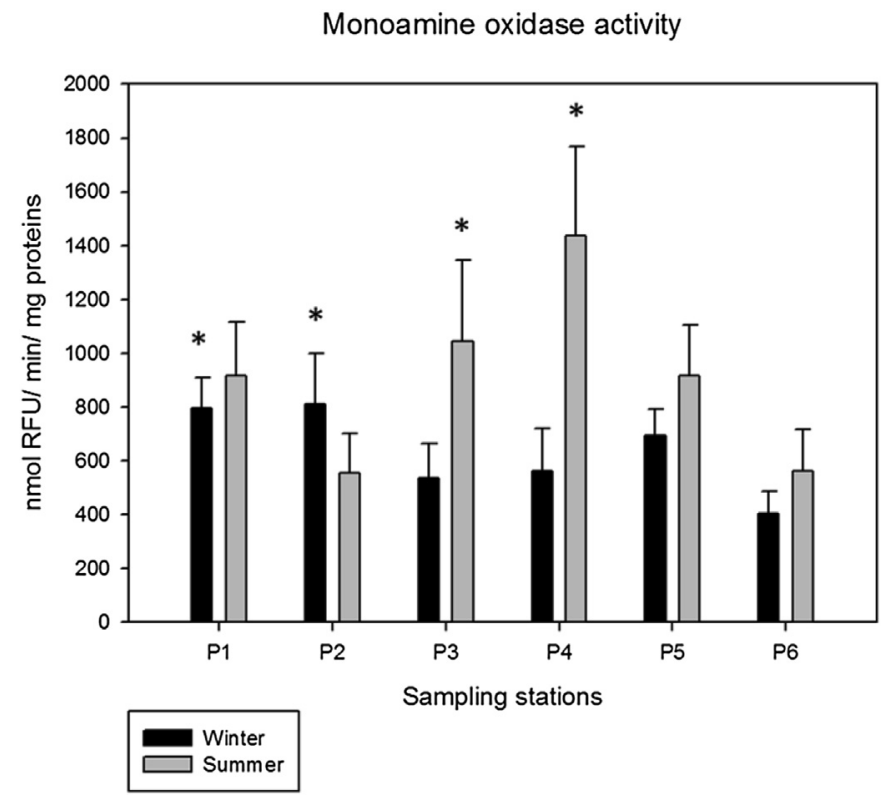

Fig. 3. Monoamine oxidase (MAO) activity in clams exposed to marine sediment affected by wastewater discharges. Clams $R$. philippinarum were exposed to the sediments for 14-days under laboratory conditions. RFU: relative fluorescein units. Asterisks $\left({ }^{*}\right)$ indicate significance at $\mathrm{p}<0.05$ level in respect to control clams.

Clams exposed to sediments sampled in winter showed higher TLP content (Fig. 6), being P1 (1.9-fold), P2 (2.5-fold) and P3 (1.9fold) significantly increased compared with the reference site $(\mathrm{p}<0.05)$. Clams showed lower TLP in summer compared with winter, however, P1 (2.4-fold) showed significantly higher TLP content compared with control clams ( $\mathrm{p}<0.05$ ).

Respiratory metabolism of clams exposed to marine sediments affected by wastewater discharges were determined by mitochondrial electron transport (MET) activity (Fig. 7). During winter, 
Alkali-labile phosphate levels

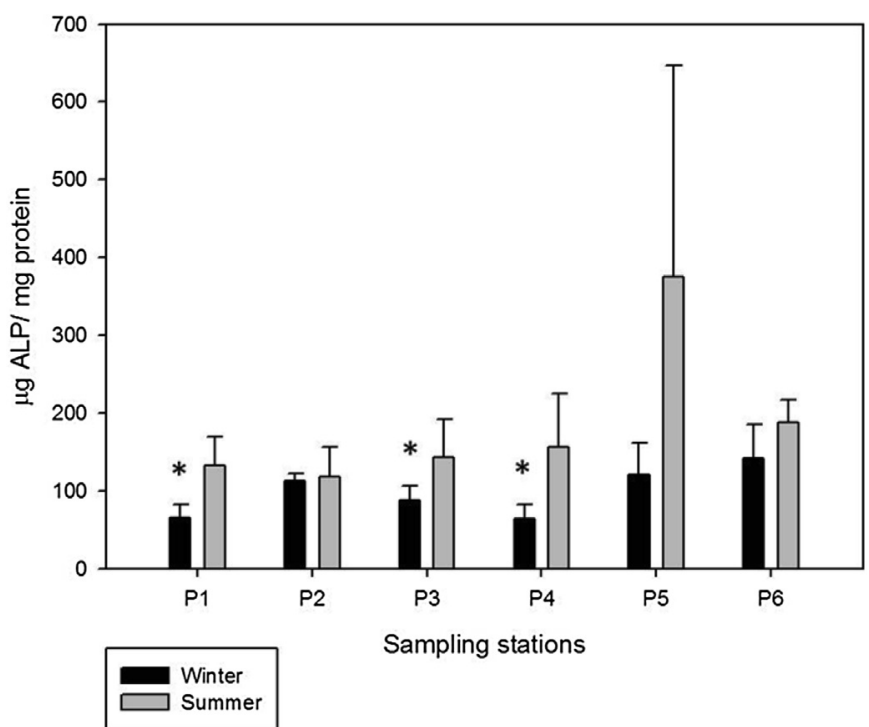

Fig. 4. Alkali-labile phosphate (ALP) levels in clams exposed to marine sediment affected by wastewater discharges. Clams $R$. philippinarum were exposed to the sediments for 14-days under laboratory conditions. Asterisks $\left({ }^{*}\right)$ indicate significance at $\mathrm{p}<0.05$ level in respect to control clams.

\section{Cyclooxygenase activity}

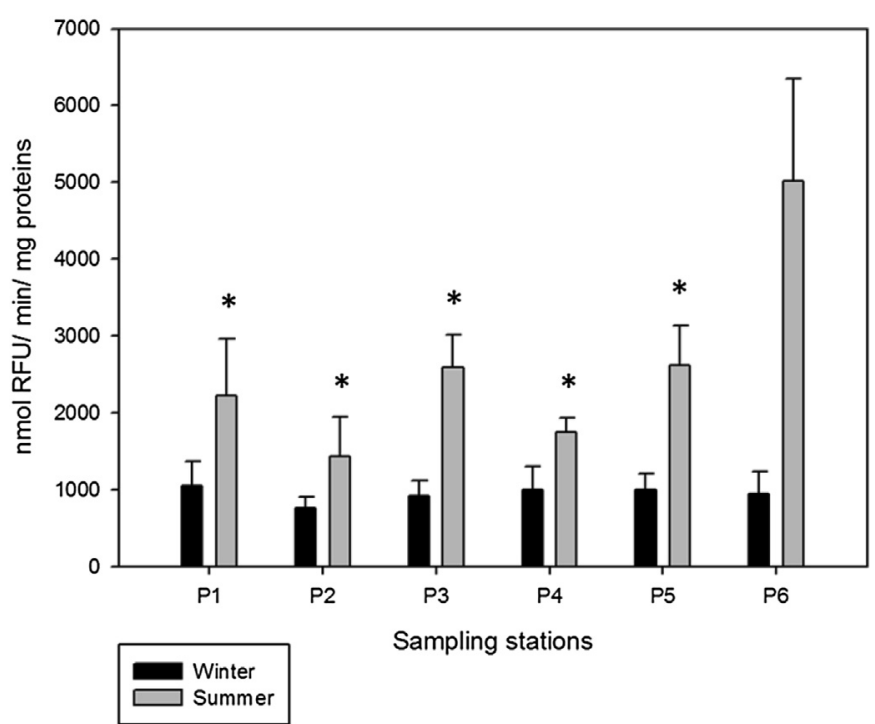

Fig. 5. Cyclooxygenase (COX) activity in clams exposed to marine sediment affected by wastewater discharges. Clams R. philippinarum were exposed to the sediments for 14days under laboratory conditions. RFU: relative fluorescein units. Asterisks $\left({ }^{*}\right)$ indicate significance at $\mathrm{p}<0.05$ level in respect to control clams.

there was no significant difference for any station compared with the reference site. However, P4 and P5 (2.1-fold) showed significant decrease in MET activity in summer $(\mathrm{p}<0.05)$.

\subsection{Correlation between biomarker responses}

Concerning P1 in winter, there was no correlation between biomarker responses. In summer, TLP was positively correlated with dopamine, ALP levels and MAO activity $(\mathrm{r}=1, \mathrm{p}<0.01)$. TLP and COX activity were negatively correlated $(r=-1, p<0.01)$.
Total lipids

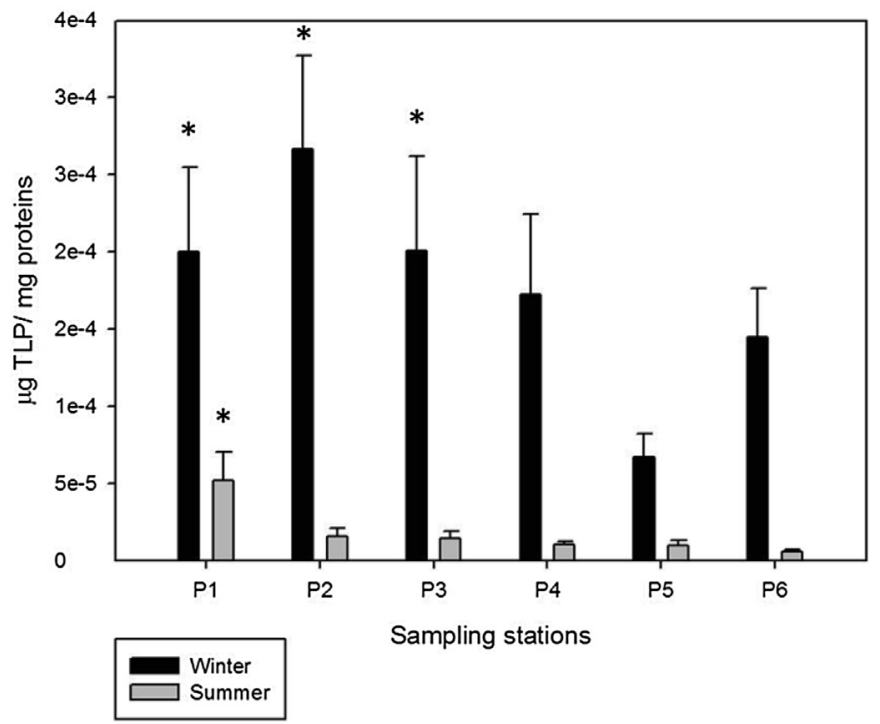

Fig. 6. Total lipids (TLP) content in clams exposed to marine sediment affected by wastewater discharges. Clams R. philippinarum were exposed to the sediments for 14days under laboratory conditions. Asterisks $\left({ }^{*}\right)$ indicate significance at $\mathrm{p}<0.05$ level in respect to control clams.

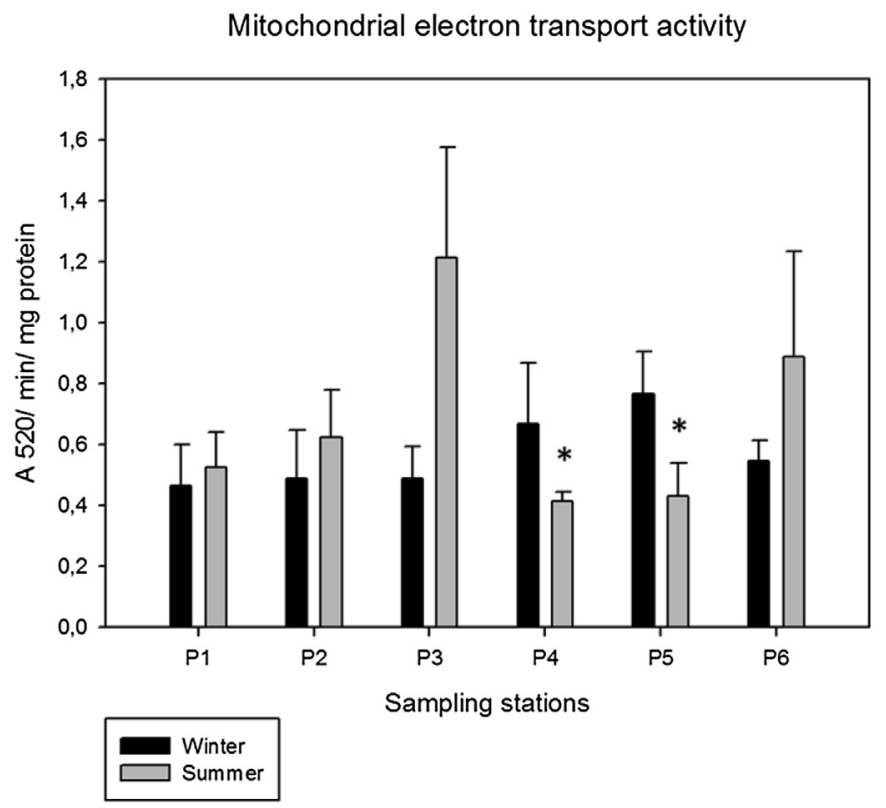

Fig. 7. Mitochondrial electron transport (MET) activity in clams exposed to marine sediment affected by wastewater discharges. Clams $R$. philippinarum were exposed to the sediments for 14-days under laboratory conditions. A 520: absorbance at $520 \mathrm{~nm}$. Asterisks $\left({ }^{*}\right)$ indicate significance at $\mathrm{p}<0.05$ level in respect to control clams.

Dopamine was also positively correlated with MET activity $(r=1$, $\mathrm{p}<0.01$ ).

Biomarker responses determined in clams exposed to P2 in winter showed positive correlation of MET activity, TLP $(r=.9$, $\mathrm{p}<0.05)$ and COX activity $(\mathrm{r}=1, \mathrm{p}<0.01)$. MET activity was also negatively correlated with MAO activity $(\mathrm{r}=-1, \mathrm{p}<0.01)$. Dopamine and ALP levels were negatively correlated $(\mathrm{r}=-1, \mathrm{p}<0.01)$. Clams exposed in summer showed positive correlation between COX activity and TLP $(\mathrm{r}=.9, \mathrm{p}<0.05)$. ALP levels were positively correlated with MAO activity $(\mathrm{r}=1, \mathrm{p}<0.01)$, and negatively 
correlated with dopamine $(\mathrm{r}=-1, \mathrm{p}<0.01)$.

Positive correlation was observed between TLP and dopamine in clams exposed to sediment sampled at P3 in winter $(\mathrm{r}=1, \mathrm{p}<0.01)$. No correlation was observed in summer season.

Clams exposed to sediment sampled at P4 in winter showed positive correlation between dopamine, MET and COX activities $(\mathrm{r}=1, \mathrm{p}<0.01)$. In summer, COX activity was negatively correlated with ALP levels and MET activity $(\mathrm{r}=-1, \mathrm{p}<0.01)$. MAO activity was positively correlated with dopamine and MET activity $(r=1$, $\mathrm{p}<0.01)$, and negatively correlated with ALP levels $(\mathrm{r}=-1$, $\mathrm{p}<0.01)$.

In winter, clams exposed to P5 showed positive correlation between ALP levels and COX activity $(r=.9, p<0.05)$, and negative correlation with MET activity $(\mathrm{r}=-.9, \mathrm{p}<0.05)$. In summer, MAO activity and ALP levels were negatively correlated $(r=-1, p<0.01)$.

P6 was considered the reference site. Clams exposed to this sediment samples showed positive correlation between COX and MAO activities $(\mathrm{r}=1, \mathrm{p}<0.01)$. However, MAO and MET activities, and TLP and ALP levels were negatively correlated $(r=-1, p<0.01)$. In summer, TLP was positively correlated with dopamine, MAO and MET activities $(r=1, p<0.01)$. MET activity was also positively correlated with ALP levels $(r=1, p<0.01)$.

\subsection{Integrated approach}

The PCA analysis was performed with chemical data and biomarker responses from winter and summer (Table 3 ). In winter, three factors axes explained $90.34 \%$ of the total variance. Positive correlations of factor 1 explained $32.55 \%$ of variance, and related TLP and dopamine levels with contamination by PAHs, metals (Al, $\mathrm{Cu}, \mathrm{Ni}, \mathrm{Zn}, \mathrm{Pb}$ ) and pharmaceutical products (others) associated with TOC and OM in the sediment. Negative correlations linked MET and COX activities with psychiatric drugs associated with \% of fines in the sediment. Factor 2 accounted for $31.51 \%$ of variances, and positive correlations explained the relationship between MAO activity and dopamine levels related with contamination by metals (Al, Fe, Mn, Cr, Zn, Ni, As), pharmaceuticals (anti-inflammatories, lipid regulators, others) and SAS associated with OM content in the sediment. Factor 3 explained $26.28 \%$ of the variance. Positive loadings linked COX activity with contamination by metals $(\mathrm{Cr}, \mathrm{Cu})$ and pharmaceutical products (anti-inflammatories, antihypertensive, lipid regulators). Negative loadings grouped ALP levels with PAHs and pharmaceutical products (antibiotics) associated with \% of fines in the sediment.

The second PCA was concerning summer data. Factor 1 explained $31.65 \%$ of the total variance. Positive loadings represented contamination by PAHs, metals ( $\mathrm{Al}, \mathrm{Fe}, \mathrm{Cr}, \mathrm{Ni}, \mathrm{Zn}$ ), SAS and pharmaceutical products (others) associated with TOC and OM in the sediment. Negative loadings of the factor 1 showed the relationship between dopamine, MET and COX activities due contamination by $\mathrm{Cd}$. Factor 2 accounted for $27.30 \%$ of the original variance and it grouped, with positive loadings, TLP, metals ( $\mathrm{Al}, \mathrm{Fe}, \mathrm{Cr}, \mathrm{Ni}$ ) and pharmaceuticals products (anti-inflammatories, lipid regulators, psychiatric drugs, antibiotics, antacids, others) concentrations. Factor 3 explained $24.02 \%$ of the total variance. Positive loadings of factor 3 showed metal $(\mathrm{Cu}, \mathrm{Zn}, \mathrm{Pb})$ and pharmaceutical products (anti-hypertensive drugs and others) presented in the sediment related to TOC, which affected MET activity. Negative loading showed ALP levels related with metals (Mn, As) and \% of fines in the sediment.

The weight of factors at each sample site concerning both seasons was shown in Fig. 8. In winter, factor 1 exhibited a positively predominant score for P2 and a negatively predominant score for P5. While factor 2 was positively dominant in the case of P1 and P2, P3 showed the negative predominance. Factor 3 grouped variables with positive coefficients predominant in $\mathrm{P} 1$ and $\mathrm{P} 4$, and negative variables predominant in P2 and P5. In summer, factor 1 variables with positive loadings were important in $\mathrm{P} 2$, and negative loadings

Table 3

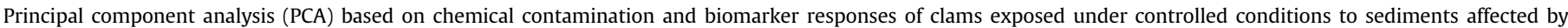
wastewater discharges at the Bay of Cádiz (SW, Spain) in winter and summer.

\begin{tabular}{|c|c|c|c|c|c|c|}
\hline \multirow[t]{2}{*}{ Variables } & \multicolumn{3}{|l|}{ Winter } & \multicolumn{3}{|l|}{ Summer } \\
\hline & \#1 32.55\% & \#2 31.51\% & \#3 26.28\% & \#1 31.65\% & \#2 27.30\% & \#3 24.02\% \\
\hline TLP & .974 & & & & .822 & \\
\hline MET & -.844 & & & -.537 & & .547 \\
\hline MAO & & .882 & & & & \\
\hline Dopamine & .613 & .669 & & -.959 & & \\
\hline ALP & & & -.974 & & & -.764 \\
\hline $\operatorname{cox}$ & -.686 & & .623 & -.701 & & \\
\hline PAHs & .760 & & -.542 & .700 & -.559 & \\
\hline $\mathrm{Al}$ & .503 & .725 & & .762 & .606 & \\
\hline $\mathrm{Fe}$ & & .805 & & .811 & .551 & \\
\hline Mn & & .888 & & & & -.960 \\
\hline $\mathrm{Cr}$ & & .680 & .511 & .769 & .556 & \\
\hline $\mathrm{Cu}$ & .785 & & .510 & & & .860 \\
\hline $\mathrm{Ni}$ & .503 & .694 & & .752 & .532 & \\
\hline Zn & .709 & .516 & & .638 & & .629 \\
\hline $\mathrm{Pb}$ & .957 & & & & & .880 \\
\hline Cd & & -.992 & & -.848 & & \\
\hline As & & .895 & & & & -.551 \\
\hline Anti-inflammatories & & .558 & .760 & & .869 & \\
\hline Anti-hypertensive & & & .886 & & & .883 \\
\hline Lipid regulators & & .500 & .509 & & .878 & \\
\hline Psychiatric & -.876 & & & & .968 & \\
\hline Antibiotics & & & -.938 & & .964 & \\
\hline Antacids & & & & & .756 & \\
\hline Others & .513 & .695 & & .520 & .510 & .578 \\
\hline SAS & & .748 & & .852 & & \\
\hline \% Fines & -.505 & & -.849 & & & -.617 \\
\hline TOC & .951 & & & .756 & & 609 \\
\hline OM & .506 & .686 & & .905 & & \\
\hline
\end{tabular}




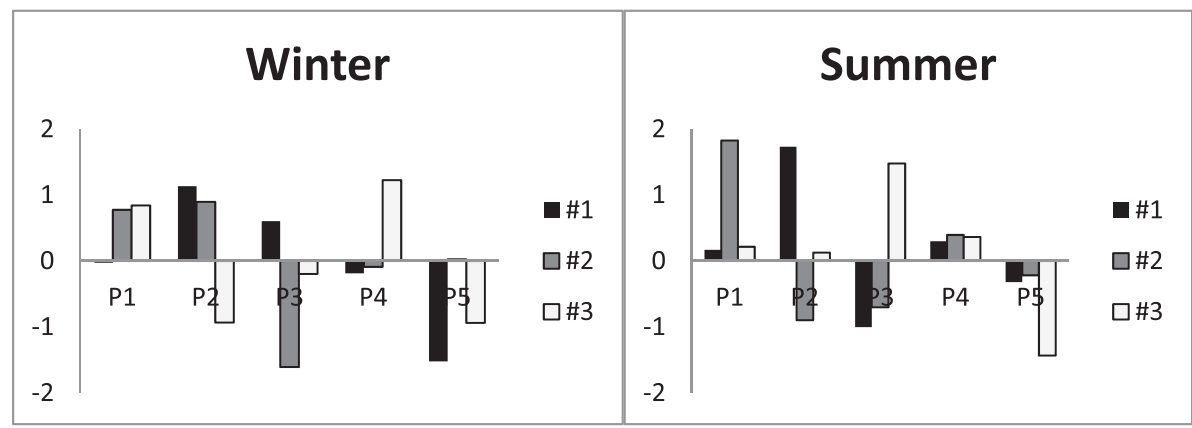

Fig. 8. Factor scores of the five sediment sampling sites evaluated at the Bay of Cádiz (P1, P2, P3, P4 and P5) during winter and summer seasons.

were important in P3. Factor 2 was positively dominant in P1, and negatively dominant in P2 and P3. Factor 3 showed positive scores and high dominance in P3. Factor 3 score was negatively predominant in $\mathrm{P5}$.

\section{Discussion}

According to data from the Ministry of Environment of the Junta de Andalucía (Spain), Cádiz and San Fernando spend up water during summer an average of $59 \%$ over winter months which reflect directly to the volume of wastewater discharges. Wastewater treatment consists of a set of physical, biological and chemical operations that seek to eliminate organic matter and contaminants before discharge; however levels of contamination remaining in the treated effluents meet the existing legal limits. Nevertheless, even after treatments, wastewater presented toxicity to organisms exposed to effluents (Gagné et al., 2007a,b, 2008a,b). Sediment sampled at P4 in winter showed high mortality of clams, which could be related with contamination by $\mathrm{Hg}$ and pharmaceuticals as anti-inflammatories, antihypertensive, psychiatric drugs and antibiotics, when comparing winter and summer seasons.

Marine sediment sampled near different WWTPs discharges at the Bay of Cádiz affected the clams in a different way depending of the locations and seasons. Seasonal changes in the biochemical components have been studied in $R$. philippinarum (FernandezReiriz et al., 2007) in North Spain. Fernandez-Reiriz et al. (2007) observed that clams $R$. philippinarum used their own energy reserves (carbohydrates and glycogen) for sexual development in high temperature situations $\left(18{ }^{\circ} \mathrm{C}\right)$, while on low temperature conditions $\left(14^{\circ} \mathrm{C}\right)$ was produced an accumulation of reserves. In the present study, $R$. philippinarum increased the lipids content (TLP) in gonads during winter when compared with clams exposed during summer. Therefore, positive energy balances permitted clams gonadal development and reserves accumulation of both low and high temperature conditions (Fernandez-Reiriz et al., 2007).

In general, the pattern followed by each biomarker response observed in clams exposed to the reference site (P6) was closely related to the state of sexual maturity and the use of previously stored reserves. Clams exposed to sediment sampled at reference site showed different correlations according to seasons. In winter, COX and MAO activities were positively correlated ( $<<0.01$ ). MAO activity has the function to break down neurotransmitters such as noradrenaline, serotonin and dopamine. Increase of MAO enzymatic activity can provide free radicals due to the oxidation of neurotransmitters, culminating on harm the neurons that produce dopamine. Evidence for MAO activity in bivalve molluscs is compelling based on previous studies (Sloley, 2004). Increase of COX activity deals with inflammatory properties, but also with spawning phase which normally occurs during summer for this specie. Decrease of COX activity could be due the increase of NSAIDs use for the population during summer.

Bivalve molluscs have been shown seasonal changes in biomass of soft tissue and its relation to the reproductive cycle reflects a complex interaction between external environmental factors and endogenous response (regulated by neuroendocrine system). Morthorst et al. (2014) applied ELISA to one freshwater bivalve species and compared the results with ALP methods. In fact, ELISA seems more sensitive method than ALP. However, Porte et al. (2006) brings many examples of the application of ALP methods in bivalves, mainly because there are few specific antibodies developed against bivalve Vtg or Vtg-like molecules, and these antibodies usually show low cross-reactivity across species ( Li et al., 2008; Blaise et al., 1999; Kang et al., 2003; Osada et al., 2003; Park and Choi, 2004). Matozzo et al. (2012) observed that Triclosan was not oestrogenic to the clam $R$. philippinarum through the application of ALP methods. Therefore, seasonality studies in different bivalve molluscs have shown that ALP levels follow the same trend of the gametogenic cycle in females (Blaise et al., 1999; Ortiz-Zarragoitia and Cajaraville, 2005).

Within the same species, periods of reserves mobilization may change between locations, once the stages of reproductive cycle and energy reserves may be influenced by exogenous factors. Lipids form part of the reserves and are also important component of bivalve oocytes. Invertebrate reproduction is energy intensive (Brooks et al., 2003). Their maximum levels occur in the prespawning period before summer. The accumulation of reserves, allocation of stored energy to somatic growth or to the germinal pathway, and importance of each biochemical response to the reproductive process play a special role in the strategies to environmental stresses. Although there is a positive correlation between ALP levels, TLP and MET, according to Baek et al. (2014) lipids are important to maintaining the embryonic and larval development, while glycogen is used for gamete production and metabolic maintenance. Glycogen content should bring additional information about reproduction effects in clams. Temperature and food availability influences clams' reproduction (Fernandez-Reiriz et al., 2007; Ojea et al., 2004). In the present study, clams were exposed under controlled temperature and there was no scarce of food resources, since the sediment affected by wastewater discharges were fulfilled of nutrients. However, wastewaters discharges produced different effects at all levels examined within the same season on different sites due to contamination.

The Bay of Cádiz (SW, Spain) is an area with great ecological and economic relevance. Differences on biochemical responses between sites in the same season should be due the different wastewater treatments. Volume of wastewater discharged per day by each WWTP or pumping stations was different. However, volume along the seasons in the year of 2011 did not vary significantly, because the rain in winter might be compensated by the increase of population and water discharge during the summer. Composition 
of the wastewater discharges changed, being the main stress for the organisms, even the volume kept around the same along the year. Such information can be found at https://www.apemsa.es/valoresde-depuracion, http:/www.aqualia-infraestructuras.es/ referencias.cfm?idArtCat=12, https://chiclananatural.com/datosy-estadisticas/agua/.

To extrapolate the same behaviour for $R$. philippinarum, and considering P6 as a good reference site, clams exposed to sediments sampled at P1 (Chiclana de la Frontera) did not show correlation between biomarker responses during winter. In summer, COX activity was negatively correlated with TLP $(\mathrm{p}<0.01)$, which was positively correlated with ALP levels $(\mathrm{p}<0.01)$. However, the energy required to support anti-inflammatory properties by endogenous or exogenous inputs of NSAIDS contaminants represents expenditure for bivalves, as corroborated by the negative correlation between COX activity and TLP.

In summer, there was no significant increase of ALP levels compared with the reference site. The same happened at the Seine estuary, since ALP levels in mussels from polluted sites were not significantly induced compared with the least-polluted site (Gagné et al., 2008b). Vtg-like proteins are the precursor of the energy reserves for the embryos, composed by lipid phosphorylated proteins. The exposure of clams to sediment affected by wastewater discharges produced marked increase in energy reserves (lipids in the gonads) which was positively related to ALP levels in summer. In winter, ALP levels were significantly lower than the reference site $(\mathrm{p}<0.05)$ and MAO activity was significant higher than the reference site $(p<0.05)$. Previous study showed mussels exposed to urban contaminants produced marked increase in energy reserves and lipids in the gonads (Gagné et al., 2001).

The most contaminated site was $\mathrm{P} 2$ which presented a modified granulometric distribution and under influence of wastewater discharges (Carrasco et al., 2003). Lara-Martín et al. (2008) measured various organic compounds including linear alkylbenzene sulfonates (LAS), nonylphenol polyethoxylates (NPEOs), polycyclic aromatic hydrocarbons (PAHs), polychlorinated biphenyls (PCBs) and organochlorinated pesticides in sediments of the Bay of Cádiz. In general, the highest concentrations of these organic compounds were found in surface sediments near the untreated urban effluents (Lara-Martín et al., 2008). Variations on metal concentrations ( $\mathrm{Pb}, \mathrm{Zn}, \mathrm{Cd}, \mathrm{Cu}$ ) were observed with the distance from the urban and industrial effluents at the Bay of Cádiz (Ponce et al., 2000). Diversity and abundance of xenobiotics (e.g. xenoestrogens) in aquatic environments suggests significant potential for adverse effects on reproduction (Doyle et al., 2013). MAO activity and TLP were significantly higher than the reference site in winter $(\mathrm{p}<0.05)$. In summer season, clams exposed to sediments from P2 showed significantly lower dopamine levels and COX activity compared with the reference site $(p<0.05)$. Reduced levels of dopamine in clams exposed to P2 during summer might represent loss of susceptibility and an adaptive response to oxidative stress, as previously reported for mussels exposed to municipal effluents (Gagné et al., 2007a).

Positive correlation was observed between TLP and dopamine levels in clams exposed to sediment sampled at P3 (Cádiz) in winter $(\mathrm{p}<0.05)$. In this season, clams seemed to reserve lipids and do not increase ALP levels. However, there was no significant correlation between biomarker responses in clams exposed in summer. Energy reserves seemed to be more associated towards MAO and COX activities.

Previous study with some sites in common with the present study classified the Bay of Cádiz as moderated contaminated (Carrasco et al., 2003). A station located near P4 showed high faecal coliforms values, which in conjunction with physical-chemical analyses, confirmed the existence of domestic and industrial uncontrolled discharges in this area (Carrasco et al., 2003). Concerning two points located at the city of El Puerto de Santa Maria (P4 and P5), clams exposed in winter to sediment collected at P4 showed positive correlation between COX activity and dopamine levels $(\mathrm{p}<0.01)$, which dopamine was positively correlated with MET activity and ALP levels ( $\mathrm{p}<0.01$ ). Energy required to support vitellogenesis and by endogenous or exogenous inputs of oestrogenic contaminants represents another major expenditure for bivalves, thus contributing to the increase in energy demands (Smolders et al., 2004), as corroborated by the correlation between ALP levels and MET activity. Previous study on the scallop Argopecten purpuratus during vitellogenesis showed the increase of dopamine and serotonin levels, and COX enzymatic activity for final gamete maturation, fertilization and spawning steps (Martinez and Rivera, 1994). However, COX activity decreased in clams exposed during summer, MAO increased, but dopamine levels did not increase which means no spawning.

In winter, COX activity was positively correlated with ALP levels $(\mathrm{p}<0.05)$, which was negatively correlated with MET activity $(\mathrm{p}<0.05)$ in clams exposed to sediment sampled at P5. A secondary role of ALP levels might be involved in the immune response. Gagné et al. (2011) observed a significant correlation between Vtg-like proteins and the phagocytic efficiency index, involved in the immunocompetence of mussels exposed to municipal effluents. Vtg-like proteins have been associated with infection-resistant response which plays an integrative function in regulating immunity via its pleiotropic effects on both recognizing pathogenassociated molecular patterns and promoting macrophage phagocytosis in fish (Li et al., 2008).

MAO activity was negatively correlated with ALP levels $(\mathrm{p}<0.01)$ in clams exposed to sediment from P5 in summer. MAO activity significantly increased in clams exposed to P1 and P2 in winter, and P3 and P4 in summer $(\mathrm{p}<0.05)$. Previous study showed that MAO activity was induced in caged mussels exposed to urban effluent plume (Gagné and Blaise, 2003). The main role of MAO activity is the oxidative catabolism of important amine neurotransmitters, including serotonin, dopamine and adrenaline. Monoamines (e.g., serotonin and dopamine) are important mediators of gamete maturation and spawning (Gagné et al., 2007b). Selective serotonin reuptake inhibitor (SSRIs), as anti-depressive drugs, works as MAO inhibitors. The increase of MAO activity can be due progesterone products, therefore, reduce dopamine levels, increase free radicals and oxidative stress (Edmondson et al., 2009), and it is associated to oocyte maturation (Brooks et al., 2003).

Indeed, the correlation between dopamine levels and ALP levels in winter suggests gametogenesis where a neuroendocrine interaction between signalling and dopamine metabolism in clams exposed to sediment affected by WWTP effluents (P2 and P4). At the end of gametogenesis, dopamine levels drops and serotonin increases to finalize gamete maturation, to initiate egg release as with COX activity (Gagné et al., 2011). However, COX activity significantly decreased in summer for clams exposed to all stations compared with the reference site $(\mathrm{p}<0.05)$. Oestrogenic signalling may keep the clams in gametogenesis stage rather than spawning (Matozzo et al., 2008). This could be due the fact that municipal effluent contaminants such as oestrogenic compounds and non-steroidal anti-inflammatory drugs (NSAIDs) present in wastewater discharges could inhibit COX activity in summer, which could result in negative impacts on spawning. Previous studies showed the presence of NSAIDs in wastewater discharges (Hernando et al., 2006; Scheytt et al., 2005; Loffler and Ternes, 2003). The class of compounds detected at highest concentrations in sediments sampled in Ebro River were analgesics/anti-inflammatory drugs followed by $\beta$ agonists and some antibiotics, which ibuprofen was the most abundant pharmaceutical product detected (Da Silva et al., 2011). 
High mortality rates in winter and impaired reproduction mainly in summer should affect the equilibrium of the population. Based on this information, it is expected less individuals and delay in reproduction, which can result in the reduction of the clams' population in the future. To evaluate the bioavailability and help to elucidate which one (s) of the contaminant from the sediment are really engaged in the observed effects, efforts must take into account bioaccumulation, sex identification and histology of gonads.

\section{Conclusion}

This study underscores the contamination of the Bay of Cádiz by anthropic activities and the impact of wastewater discharges, responsible for effects related to reproduction of the biota exposed. Such effects are associated to oxidative metabolism, stress endpoints and the reproductive stage, and could culminate in long-term changes affecting the population. Wastewater discharges composition changed between different seasons, as the biochemical responses, mainly leading to oxidative stress and inflammation (COX activity). Observed effects are consistent with the occurrence of pharmaceutical products, PAHs, metals and surfactants. The exposure to municipal effluents seems to keep clams in a gametogenesis stage and delayed spawning based on the presented results. Further investigation should encompass the spawning activity in clams exposed to municipal effluent and to determine whether this process is disrupted. Thus, the continuous release of wastewater discharges adequately threated or not in aquatic ecosystems poses a reproduction risk to the clams' R. philippinarum.

\section{Acknowledgements}

This research was partially funded by project P09-RNM-5136 (Government of Andalusia, Spain), European Regional Development Fund (FEDER) and CAPES/MEC (Brazil) (doctoral grant to the first author, ref. 0362-10/7). The first author thanks the University of Cádiz for the financial support for the short-research stay at the Environment Canada.

\section{References}

Baek, M.J., Lee, Y.J., Choi, K.S., Lee, W.C., Park, H.J., Kwak, J.H., Kang, C.K., 2014 Physiological disturbance of the Manila clam, Ruditapes philippinarum, by altered environmental conditions in a tidal flat on the west coast of Korea. Mar Poll. Bull. 78 (1-2), 137-145.

Baena-Nogueras, R.M., González-Mazo, E., Lara-Martín, P.A., 2013. Determination and occurrence of secondary alkane sulfonates (SAS) in aquatic environments. Environ. Poll. 176, 151-157.

Beyer, J., Aarab, N., Tandberg, A.H., Ingvarsdottir, A., Bamber, S., Børseth, J.F., Camus, L., Velvin, R., 2013. Environmental harm assessment of a wastewater discharge from Hammerfest LNG: a study with biomarkers in mussels (Mytilus sp.) and Atlantic cod (Gadus morhua). Mar. Poll. Bull. 69 (1-2), 28-37.

Blaise, C., Gagné, F., Pellerin, J., Hansen, P.D., 1999. Determination of vitellogeninlike properties in Mya arenaria hemolymph (Saguenay Fjord, Canada): a potential biomarker for endocrine disruption. Environ. Toxicol. 14, 455-465.

Box, A., Sureda, A., Galgani, F., Pons, A., Deudero, S., 2007. Assessment of environmental pollution at Balearic Islands applying oxidative stress biomarkers in the mussel Mytilus galloprovincialis. Comp. Biochem. Physiol. 146 (Part C), 531-539.

Bradford, M.B., 1976. A rapid and sensitive method for the quantification of microgram quantities of protein utilizing the principle of protein-dye binding. Anal. Biochem. 72, 248-254.

Brooks, B.W., Foran, C.M., Richards, S.M., Weston, J., Turner, P.K., Stanley, J.K., Solomon, K.R., Slaterry, M., La Point, T.W., 2003. Aquatic ecotoxicology of fluoxetine. Toxicol. Lett. 142 (3), 169-183.

Buratti, S., Fabbri, E., Pereira, C.D.S., Ramos-Gómez, J., Del Valls, T.A., MartínDíaz, M.L., 2010. Application of neutral red retention assay in the clam Ruditapes philippinarum and the crab Carcinus maenas as a screening tool for sediment quality assessment in marine environment. Comp. Biochem. Physiol. A 157, S27.

Buratti, S., Ramos-Gómez, J., Fabbri, E., Delvalls, T.A., Martín-Díaz, M.L., 2012 Application of neutral red retention assay to caged clams (Ruditapes decussatus) and crabs (Carcinus maenas) in the assessment of dredged material. Ecotoxicology 21, 75-86.
Carrasco, M., Lopez-Ramírez, J.A., Benavente, J., Lopez-Aguayo, F., Sales, D., 2003. Assessment of urban and industrial contamination levels in the bay of Cádiz, SW Spain. Mar. Poll. Bull. 46 (3), 335-345.

CCME (Canadian Council of Ministers of the Environment), 1995. Protocol for the Derivation of Canadian Sediment Quality Guidelines for the Protection of Aquatic Life. CCME EPC-98E. Prepared by Environment Canada. Guidelines Division, Technical Secretariat of the CCME Task Group on Water Quality Guidelines, Ottawa [Reprinted in Canadian environmental quality guidelines, Chapter 6. Canadian Council of Ministers of the Environment, 1999, Winnipeg.] Sediment Quality Guidelines for the Protection of Aquatic Life (Canadian Environmental Quality Guidelines).

CCME (Canadian Council of Ministers of the Environment), 1999. Canadian sediment quality guidelines for the protection of aquatic life: polycyclic aromatic hydrocarbons (PAHs). In: Canadian Environmental Quality Guidelines, 1999. Canadian Council of Ministers of the Environment, Winnipeg.

CEDEX (Centro de Estudios y Experimentación de Obras Públicas), 1994. Recomendaciones para la gestión del material de dragado en los puertos Españoles. Centro de Estudios y Experimentación de Obras Públicas, Puertos del Estado, Madrid.

Comreys, A.L., 1973. A First Course in Factor Analysis. Academic Press, New York.

Coughlan, B.M., Moroney, G.A., van Pelt, F.N.A.M., O'Brien, N.M., Davenport, J., O'Halloran, J., 2009. The effects of salinity on the Manila clam (Ruditapes philippinarum) using the neutral red retention assay with adapted physiological saline solutions. Mar. Poll. Bull. 58 (11), 1680-1684.

Da Silva, B.F., Jelic, A., López-Serna, R., Mozeto, A.A., Petrovic, M., Barceló, D., 2011. Occurrence and distribution of pharmaceuticals in surface water, suspended solids and sediments of the Ebro river basin, Spain. Chemosphere 85 (8), 1331-1339.

Doyle, M.A., Bosker, T., Martyniuk, C.J., Maclatchy, D.L., Munkittrick, K.R., 2013. The effects of 17- $\alpha$-ethinylestradiol (EE2) on molecular signaling cascades in mummichog (Fundulus heteroclitus). Aquat. Toxicol. 134-135, 34-46.

Edmondson, D.E., Binda, C., Wang, J., Upadhyay, A.K., Mattevi, A., 2009. Molecular and mechanistic properties of the membrane-bound mitochondrial monoamine oxidases. Biochemistry 48 (20), 4220-4230.

Fernández-Reiriz, M.J., Pérez-Camacho, A., Delgado, M., Labarta, U., 2007. Dynamics of biochemical components, lipid classes and energy values on gonadal development of R. philippinarum associated with the temperature and ingestion rate. Comp. Biochem. Phys. A 147 (4), 1053-1059.

Franzellitti, S., Buratti, S., Donnini, F., Fabbri, E., 2010. Exposure of mussels to a polluted environment: insights into the stress syndrome development. Comp. Biochem. Physiol. Toxicol. Pharma. 152 (1), 24-33.

Frings, C.S., Fendley, T.W., Dunn, R.T., Queen, C.A., 1972. Improved determination of total serum lipids by the sulfo-phosphovanillin reaction. Clin. Chem. 18, $673-674$.

Fujimoto, Y., Sakuma, S., Inoue, T., Uno, E., Fujita, T., 2002. The endocrine disruptor nonylphenol preferentially blocks cyclooxygenase-1. Life Sci. 70, 2209-2214.

Gagne, F., Blaise, C., Salazar, M., Hansen, P., 2001. Evaluation of estrogenic effects of municipal effluents to the freshwater mussel Elliptio complanata. Comp. Biochem. Physiol. 128C, 213-225.

Gagné, F., Blaise, C., 2003. Effects of municipal effluents on serotonin and dopamine levels in the freshwater mussel Elliptio complanata. Comp. Biochem. Physiol. C 136, 117-125.

Gagné, F., Blaise, C., Pellerin, J., Pelletier, E., Douville, M., Gauthier-Clerc, S., Viglino, L., 2003. Sex alteration in soft-shell clams (Mya arenaria) in an intertidal zone of the Saint-Lawrence River (Québec, Canada). Comp. Biochem. Physiol. C 134, 189-198.

Gagné, F., Bérubé, E., Fournier, M., Blaise, C., 2005. Inflammatory properties of municipal effluents to Elliptio complanata mussels-lack of effects from antiinflammatory drugs. Comp. Biochem. Physiol. C 141 (4), 332-337.

Gagné, F., Cejka, P., André, C., Hausler, R., Blaise, C., 2007a. Neurotoxicological effects of a primary and ozonated treated wastewater on freshwater mussels exposed to an experimental flow-through system. Comp. Biochem. Physiol. C 146 (4), $460-470$.

Gagné, F., Blaise, C., André, C., Gagnon, C., Salazar, M., 2007b. Neuroendocrine disruption and health effects in Elliptio complanata mussels exposed to aeration lagoons for wastewater treatment. Chemosphere 68 (4), 731-743.

Gagné, F., André, C., Cejka, P., Hausler, R., Fournier, M., Blaise, C., 2008a. Immunotoxic effects on freshwater mussels of a primary-treated wastewater before and after ozonation: a pilot plant study. Ecotox. Environ. Saf. 69 (3), 366-373.

Gagné, F., Burgeot, T., Hellou, J., St-Jean, S., Farcy, E., Blaise, C., 2008b. Spatial variations in biomarkers of Mytilus edulis mussels at four polluted regions spanning the Northern Hemisphere. Environ. Res. 107 (2), 201-217.

Gagné, F., Bouchard, B., André, C., Farcy, E., Fournier, M., 2011. Evidence of feminization in wild Elliptio complanata mussels in the receiving waters downstream of a municipal effluent outfall. Comp. Biochem. Physiol. C 153 (1), 99-106.

Garrido-Pérez, M.C. Acevedo-Merino, A., Cruz-Lázaro, M.D., Garzón-Fernández, N., Nebot-Sanz, P., Alonso, J.M.Q., Márquez, D.S., 2002. Study of the auto depuration potential of a tidal ecosystem affected by an urban sewage. Preliminary studies. In: Almorza, D., Brebbia, C.A., Sales, D., Popov, V. (Eds.), Waste Management and the Environment, Ecology and the Environment, vol. 56. Wessex Institute of Technology, Southampton, United Kingdom, p. 788.

Gust, M., Gagné, F., Berlioz-Barbier, A., Besse, J.P., Buronfosse, T., Tournier, M., Tutundjian, R., Garric, J., Cren-Olivé, C., 2014. Caged mudsnail Potamopyrgus antipodarum (Gray) as an integrated field biomonitoring tool: exposure assessment and reprotoxic effects of water column contamination. Water Res. 
$54,222-236$

Gust, M., Fortier, M., Garric, J., Fournier, M., Gagné, F., 2013. Immunotoxicity of surface waters contaminated by municipal effluents to the snail Lymnaea stagnalis. Aquat. Toxicol. 126, 393-403.

Hernando, M.D., Mezcua, M., Fernández-Alba, A.R., Barceló, D., 2006. Environmental risk assessment of pharmaceutical residues in wastewater effluents, surface waters and sediments. Talanta 69 (2), 334-342.

INE, 2011 (accessed 05 09). http://www.ine.es/jaxi/tabla.do?path=/t20/e244/ avance $/$ p02/11 $/ \&$ file $=3$ mun $11 . p x \&$ type $=$ pcaxis $\& \mathrm{~L}=1$.

ISO11466, 1995. Soil Quality-Extraction of Trace Elements Soluble in Aqua Regia. International Organization for Standardization, Switzerland.

Jelic, A., Petrovic, M., Barceló, D., 2009. Multi-residue method for trace level determination of pharmaceuticals in solid samples using pressurized liquid extraction followed by liquid chromatography/quadrupole-linear ion trap mass spectrometry. Talanta 80, 363-371.

Kang, S.G., Choi, K.S., Bulgakov, A.A., Kim, Y., Kim, S.Y., 2003. Enzyme-linked immunosorbent assay (ELISA) used in quantification of reproductive output in the pacific oyster, Crassostrea gigas, in Korea. J. Exp. Mar. Biol. Ecol. 282, 1-21.

Kim, J., Jeon, M., Paeng, K., Paeng, I.R., 2008. Competitive enzyme-linked immunosorbent assay for the determination of catecholamine, dopamine in serum. Anal. Chim. Acta 619, 87-93.

King, F., Packard, T.T., 1975. Respiration and the activity of the respiratory electron transport system in marine zooplankton. Limnol. Oceanogr. 20, 849-854.

Lara-Martín, P.A., González-Mazo, E., Petrovic, M., Barceló, D., Brownawell, B.J., 2014. Occurrence, distribution and partitioning of nonionic surfactants and pharmaceuticals in the urbanized Long Island Sound Estuary (NY). Mar. Poll. Bull. 85 (2), 710-719.

Lara-Martín, P.A., Petrovic, M., Gómez-Parra, A., Barceló, D., González-Mazo, E., 2006. Presence of surfactants and their degradation intermediates in sediment cores and grabs from the Cadiz Bay area. Environ. Poll. 144 (2), 483-491.

Lara-Martín, P.A., Gómez-Parra, A., González-Mazo, E., 2008. Sources, transport and reactivity of anionic and non-ionic surfactants in several aquatic ecosystems in SW Spain: a comparative study. Environ. Poll. 156 (1), 36-45.

Li, Z., Zhang, S., Liu, Q., 2008. Vitellogenin functions as a multivalent pattern recognition receptor with an opsonic activity. PNAS 3, 1940-1946.

Löffler, D., Ternes, T.A., 2003. Determination of acidic pharmaceuticals, antibiotics and ivermectin in river sediment using liquid chromatography-tandem mass spectrometry. J. Chromatogr. A 1021 (1-2), 133-144.

Long, E.R., Dutch, M., Weakland, S., Chandramouli, B., Benskin, J.P., 2013. Quantification of pharmaceuticals, personal care products, and prefluoroalkyl substances in the marine sediments of Puget Sound, Washington, USA. Environ. Toxicol. Chem. 32, 1701-1710.

Maranho, L.A., DelValls, T.A., Martín-Díaz, M.L., 2015. Assessing potential risks of wastewater discharges to benthic biota: an integrated approach to biomarker responses in clams (Ruditapes philippinarum) exposed under controlled conditions. Mar. Poll. Bull. $92(1-2), 11-24$.

Maranho, L.A., Garrido-Pérez, M.C., Baena-Nogueras, R.M., Lara-Martín, P.A., AntónMartín, R., DelValls, T.A., Martín-Díaz, M.L., 2014. Are WWTPs effluents responsible for acute toxicity? Seasonal variations of sediment quality at the Bay of Cádiz (SW, Spain). Ecotoxicology 24 (2), 368-380.

Martín-Díaz, M.L., Blasco, J., Canales, M.L.G., Sales, D., DelValls, T.A., 2005. Bioaccumulation and toxicity of dissolved heavy metals from the Guadalquivir Estuary after the Aznalcóllar mining spill using Ruditapes philippinarum. Arch. Environ. Contam. Toxicol. 48, 233-241.

Martín-Díaz, M.L., Blasco, J., Sales, D., DelValls, T.A., 2007. Biomarkers study for sediment quality assessment in Spanish ports using the crab Carcinus maenas and the clam Ruditapes philippinarum. Arch. Environ. Contam. Toxicol. 53, $66-76$.

Martín-Díaz, M.L., Sales, D., DelValls, T.A., 2008a. Toxicokinetic approach for the assessment of endocrine disruption effects of contaminated dredged material using female Carcinus maenas. Ecotoxicology 17 (6), 495-503.

Martín-Díaz, M.L., Jiménez-Tenorio, N., Sales, D., Delvalls, T.A., 2008b. Accumulation and histopathological damage in the clam Ruditapes philippinarum and the crab Carcinus maenas to assess sediment toxicity in Spanish ports. Chemosphere 71 (10), 1916-1927.

Martinez, G., Rivera, A., 1994. Role of monoamines in the reproductive process of Argopecten purpuratus. Invert. Reprod. Dev. 25, 167-174.

Maruya, K.A., Vidal-Dorsch, D.E., Bay, S.M., Kwon, J.W., Xia, K., Armbrust, K.L., 2012. Organic contaminants of emerging concern in sediments and flatfish collected near outfalls discharging treated wastewater effluent to the Southern California Bight. Environ. Toxicol. Chem. 31 (12), 2683-2688.

Matozzo, V., Formenti, A., Donadello, G., Marin, M.G., 2012. A multi-biomarker approach to assess effects of Triclosan in the clam Ruditapes philippinarum. Mar. Environ. Res. 74, 40-46.

Matozzo, V., Gagné, F., Marin, M.G., Ricciardi, F., Blaise, C., 2008. Vitellogenin as a biomarker of exposure to estrogenic compounds in aquatic invertebrates: a review. Environ. Int. 34 (4), 531-545.

Matozzo, V., Marin, M.G., 2007. First evidence of altered vitellogenin-like protein levels in clam Tapes philippinarum and in cockle Cerastoderma glaucum from the Lagoon of Venice. Mar. Poll. Bull. 55 (10-12), 494-504.

Morales-Caselles, C., Riba, I., Sarasquete, C., 2008. Sublethal responses in caged organisms exposed to sediments affected by oil spills. Ciencias Mar. 72 819-825.

Morthorst, J.E., Holbech, H., Jeppesen, M., Kinnberg, K.L., Pedersen, K.L. Bjerregaard, P., 2014. Evaluation of yolk protein levels as estrogenic biomarker in bivalves; comparison of the alkali-labile phosphate method (ALP) and a species-specific immunoassay (ELISA). Comp. Biochem. Physiol. Toxicol. Pharmacol. 166, 88-95.

Moschino, V., Delaney, E., Meneghetti, F., Ros, L.D.A., 2011. Biomonitoring approach with mussel Mytilus galloprovincialis (Lmk) and clam Ruditapes philippinarum (Adams and Reeve, 1850) in the Lagoon of Venice. Environ. Monit. Asses. 177 (1-4), 649-663.

Ojea, J., Pazos, A.J., Martınez, D., Novoa, S., Sánchez, J.L., Abad, M., 2004. Seasonal variation in weight and biochemical composition of the tissues of Ruditapes decussatus in relation to the gametogenic cycle. Aquaculture 238 (1-4), $451-468$

Ortiz-Zarragoitia, M., Cajaraville, M.P., 2005. Biomarkers of exposure and reproduction-related effects in mussels exposed to endocrine disruptors. Arch. Environ. Contam. Toxicol. 49, 1-9.

Osada, M., Takamura, T., Sato, H., Mori, K., 2003. Vitellogenin synthesis in the ovary of scallop Platinopecten yessoensis: control by estradiol-17 $\beta$ and the central nervous system. J. Exp. Zool. 299A, 172-179.

Park, K.I., Choi, K.S., 2004. Application of enzyme-linked immunosorbent assay for studying reproduction in the Manila clam Ruditapes philippinarum (Mollusca: Bivalvia) I. Quantifying eggs. Aquaculture 241, 667-687.

Ponce, R., Forja, J.M., Gómez-Parra, A., 2000. Influence of anthropogenic activity on the vertical distribution of $\mathrm{Zn}, \mathrm{Cd}, \mathrm{Pb}$ and $\mathrm{Cu}$ in interstitial water and coastal marine sediments (Cádiz Bay, SW Spain). Ciencias Mar. 26 (3), 479-502.

Porte, C., Janer, G., Lorusso, L.C., Ortiz-Zarragoitia, M., Cajaraville, M.P., Fossi, M.C. Canesi, L., 2006. Endocrine disruptors in marine organisms: approaches and perspectives. Comp. Biochem. Physiol. Toxicol. Pharmacol. 143 (3), 303-315.

Riba, I., Casado-Martinez, C., Forja, J.M., DelValls, T.A., 2004. Sediment quality in the Atlantic coast of Spain. Environ. Toxicol. Chem. 23 (2), 271-282.

Scheytt, T., Mersmann, P., Lindstädt, R., Heberer, T., 2005. Determination of sorption coefficients of pharmaceutically active substances carbamazepine, diclofenac, and ibuprofen, in sandy sediments. Chemosphere 60 (2), 245-253.

Solé, M., Kopecka-Pilarczyk, J., Blasco, J., 2009. Pollution biomarkers in two estuarine invertebrates, Nereis diversicolor and Scrobicularia plana, from a Marsh ecosystem in SW Spain. Environ. Int. 35 (3), 523-531.

Solé, M., Raldua, D., Barceló, D., Porte, C., 2003. Long-term exposure effects in vitellogenin, sex hormones, and biotransformation enzymes in female carp in relation to a sewage treatment works. Ecotox. Environ. Saf. 56 (3), 373-380.

Sloley, B.D., 2004. Metabolism of monoamines in invertebrates: the relative importance of monoamine oxidase in different phyla. Neurotox $25(1-2)$, $175-183$.

Smolders, R., Bervoets, L., De Coen, W., Blust, R., 2004. Cellular energy allocation in zebra mussels exposed along a pollution gradient: linking cellular effects to higher levels of biological organization. Environ. Pollut. 129, 99-112.

Stanton, M.G., 1968. Colorimetric determination of inorganic phosphate in the presence of biological material and adenosine triphosphate. Anal. Biochem. 22 27-34.

USEPA, United States Environmental Protection Agency, 2002. Short-term Methods for Estimating the Chronic Toxicity of Effluents and Receiving Waters to Freshwater Organisms, fourth ed. USEPA, Office of Water, Washington, DC. EPA821-R-02-013.

USEPA, United States Environmental Protection Agency, 2004. Region III BTAG Marine Screening Benchmarks. http://www.epa.gov/reg3hwmd/risk/eco/btag/ sbv/marine/screenbench.htm.

USEPA, United States Environmental Protection Agency, 2007. SW-846 Method 8270. Semi Volatile Organic Compounds by Gas Chromatography/Mass Spectrometry (GC/MS). USEPA, Office of Water, Washington, DC.

USGS, United States Geological Survey Open-File Report 2000. 00-358: Chapter 1: Grain-size analysis of marine sediments: methodology and data processing. Poppe L.J., Eliason A.H., Fredericks J.J., Rendigs R.R., Blackwood D. and Polloni C.F. http://pubs.usgs.gov/of/2000/of00-358/text/chapter1.html.

Vidal-Dorsch, D.E., Bay, S.M., Greenstein, D.J., Baker, M.E., Hardiman, G., Reyes, J. a, Kellin, K.M., Schlenk, D., 2014. Biological responses of marine flatfish exposed to municipal wastewater effluent. Environ. Toxicol. Chemistry/SETAC 33 (3), 583-591. http://dx.doi.org/10.1002/etc.2466.

\section{Webpages:}

https://www.apemsa.es/valores-de-depuracion.

http://www.aqualia-infraestructuras.es/referencias.cfm?idArtCat=12.

https://chiclananatural.com/datos-y-estadisticas/agua/. 